\title{
Articulation Theory in Activist Literacy Research
}

\author{
Elizabeth Bishop ${ }^{1}$
}

This paper discusses Chantal Mouffe's (1993) articulation theory in relation to recent research into urban youth organizing and activism. Unlike many schemas for meaning making around social scientific data, Mouffe's framework offers a post-structuralist political theoretical lens through which to intersubjectively undertake scholarship, foregrounding situated temporality to produce a powerfully generative tool for framing activist literacy research. Using Mouffe to discuss a recent critical literacy study with five urban youth organizers in New York City, this paper maps the articulation of the youth as activists. Dialogue around approaches to literacy learning and articulations of activism produced rich data for polyvocal write-ups of shared and divergent trajectories of youth as human rights activists and organizers. [Article copies available for a fee from The Transformative Studies Institute. E-mail address: journal@transformativestudies.org Website: http://www.transformativestudies.org (02015 by The Transformative Studies Institute. All rights reserved.]

KEYWORDS: Literacy, Activism, Youth Organizing, Articulation Theory, Post-Structuralism.

\section{INTRODUCTION}

This paper discusses a 2012 literacy study of urban youth activism in New York City. As the primary investigator and author, I collaborated on

\footnotetext{
${ }^{1}$ Elizabeth Bishop holds a Ph.D. in Language, Literacy and Culture from the University of Pittsburgh where she was a Teaching Fellow in the Department of Instruction and Learning. She has taught history, literature, writing and media in New York schools and has worked for leading youth development community organizations. Her research explores the intersections of adolescent literacy, cultural studies and international youth activism. Her first book, "Becoming Activist: Critical Literacy and Youth Organizing" is coming out from Peter Lang Publishing later this year. Bishop works at Teachers College, Columbia University and serves as a Board Member of Voices UnBroken. Address correspondence to: Elizabeth Bishop, Teachers College, Columbia University, 525 W 120th Street Box 90, New York, NY 10027, e-mail: ebishop@tc.edu.
} 